\title{
Lincoln Kirstein, Modern Dance, and the Left: The Genesis of an American Ballet
}

\author{
LYNN GARAFOLA
}

Ballet Caravan, the short-lived chamber company founded by Lincoln Kirstein ${ }^{1}$ in 1936, is mostly remembered as a high-minded but misguided experiment in presenting ballets by Americans on American subjects. With the exception of Billy the Kid (1938), which teamed Eugene Loring with composer Aaron Copland on the first of the latter's Americana classics, and to a lesser extent the Lew Christensen-Virgil Thomson-Paul Cadmus collaboration, Filling Station (1937), the repertoire did not outlast the company's five-year existence. To be sure, aspects of the enterprise proved more lasting. 'I'he 'seasoning' of a generation of young American dancers, the discovery of a generation of new American choreographers, and the tapping in Ncw York and on the road of an cducated, sophisticated audience - all contributed to the ballet 'boom' of the 1940s and the strong American presence in companies such as Ballet Theatre, Ballet International, and the Ballet Russe de Monte Carlo.

Ballet Caravan survived in part because of Kirstein's willingness to associate the company with institutions and practices peripheral to ballet. The first of these was modern dance, which helped establish the company's American identity. Ballet Caravan made its debut at the Bennington College Summer School of the Dance, ${ }^{2}$ performed at the 92 nd Street ${ }^{3}{ }^{3}$ Washington Irving High School (in the Student Dance Recitals series), ${ }^{4}$ Dance International, ${ }^{5}$ and the New School for Social Research (in its lecture-demonstration series 'The Dance in the Social Scene' $)^{6}$ - all venues closely associated with modern dance. It shared a booking agent (Frances Hawkins) with Martha Graham, a season in 1939 at the St. James Theatre that all but coincided with the debut of Ballet Theatre, ${ }^{7}$ and something of a common thrust if not a common technique: Billy the Kid and Graham's American Document - the greatest American-themed works of the late 1930 s - premiered within two months of each other. By 1937-1938 Kirstein had become a frequent contributor to Louis Horst's Dance Observer, the house organ, so to speak, of mainstream modern dance, and photographs of Ballet Caravan dancers appeared several times on the journal's cover. ${ }^{8}$ Perhaps not unexpectedly, Kirstein's Blast at Ballet, which savaged ballet directors and ballet patrons, while insisting on the need for an 'American style' in ballet, was applauded in modern dance circles. Assessing what went wrong with Ballet 


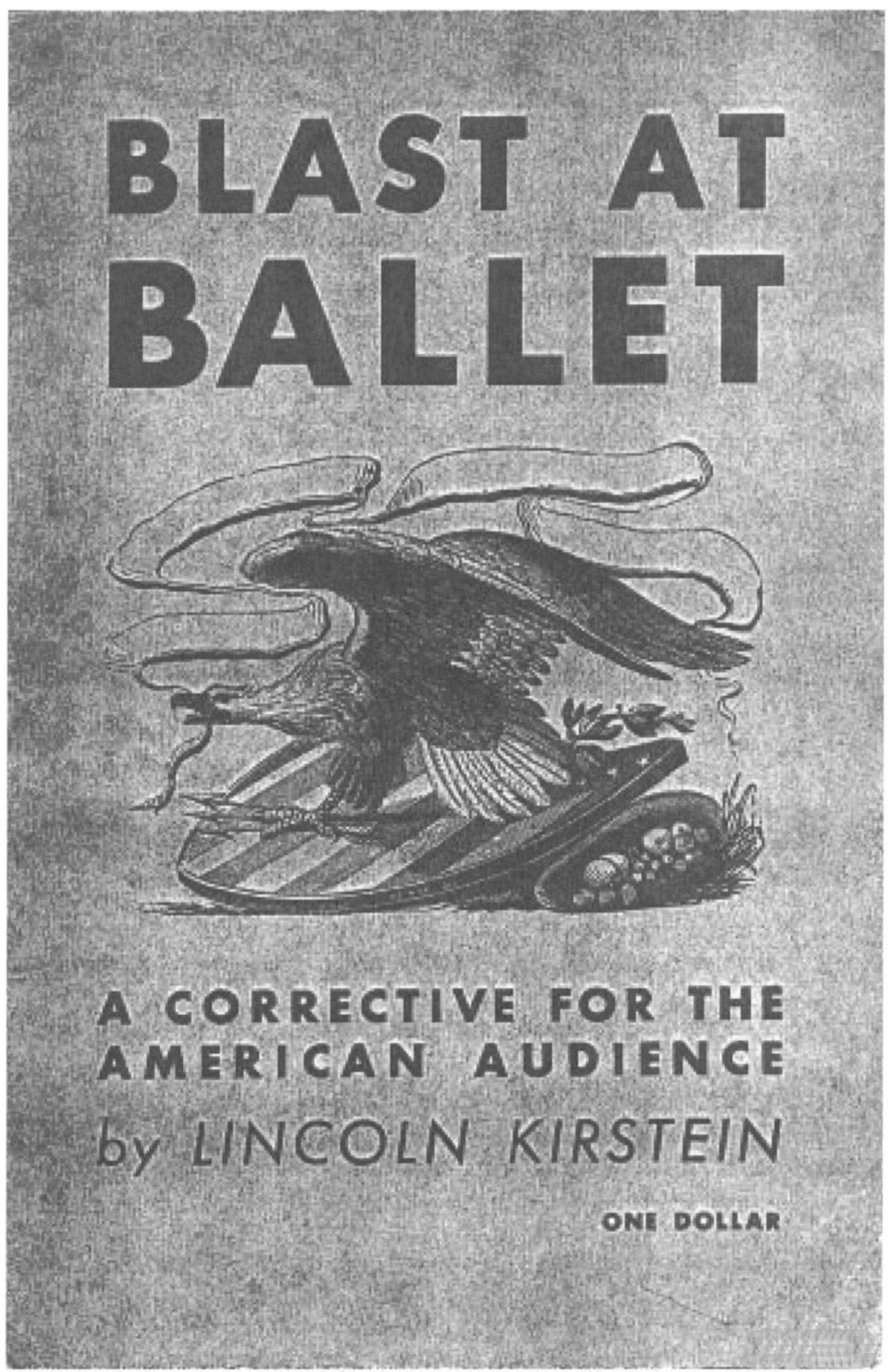

Fig. 1. Cover of Lincoln Kirstein's Blast at Ballet: A Corrective for the American Audience (1938) with the American eagle and Stars and Stripes (Private Collection). 
Caravan, Kirstein summed up the repertoire as a 'continual experiment with stray hybrids, classic ballet infused with Martha Graham movement or with Broadway revue'. ${ }^{9}$

Kirstein began his career as an impresario at a time when the United States lacked an indigenous high art tradition in ballet. Although Americans filled the lower ranks of the Metropolitan Opera ballet, most ballet-trained dancers found work on the popular stage - in Broadway musicals and revucs and in the ballet troupes attached to the Radio City Music Hall and the Roxy (where both Léonide Massine and Léo Staats worked in the 1920s and early 1930s). Many shuttled between the commercial and concert realms (the case of Radio City's 'prima ballerina' Patricia Bowman), while a few even found jobs, under suitably Russified names, with Colonel de Basil's Ballet Russe.

Kirstein's vision of a high art 'American ballet' was chiefly indebted to the model of 'British ballet'. However, in the United States the application of that model - which linked nationalism with modernism in an elite cultural practice was significantly influenced by the presence of modern dance, which by 1934 had established its primacy as a high art practice. Unlike ballet, modern dance was unambiguously American; its leading lights were American as were most of its practitioners (even if many came from New York's immigrant ghettos), and its subject matter embraced modernity and the American present. Kirstein drew upon this nationalist rhetoric in describing his new undertaking as 'ballets conceived and executed by Americans, defining, perhaps for the first time on a scale worthy of its subject, what is most lyric, indigenous, and essential in the American legend'. ${ }^{10}$ Much of the early criticism of the American Ballet, Ballet Caravan's immediate predecessor, with choreography exclusively by George Balanchine, centred on how well the company lived up to its own publicity. As John Martin, the influential dance critic of The Nerw York Times, asked in a seaching critique of the American Ballet's first 1935 season, 'is the organization to attempt the fulfillment of its original policy of developing an American ballet, or is it to follow the direction of its present season and go on being merely 'Les Ballets Americains'?"

Balanchine's appointment as the Metropolitan Opera's new ballet master in August 1935 dismayed Martin. In choosing Balanchinc the Mct had passed over 'at least half a dozen ... eminently fitted' American candidates. As for the American Ballet, moving to the Met meant abandoning the 'new, potential audience' that Kirstein had spoken of developing. Instead, Martin lamented, Balanchine would be choreographing for 'the type of audience he already knew in Furope, ... [an] audience of social position and wealth, to whom, as a rule, the ballet, when it is anything more than a diversion, is a collector's item. With the throwing of the whole organisation now into the very lap of this audience, which so largely dominates the opera house, any hope of recovering the original purpose of the enterprise appears to have been extinguished'. Martin concluded with a 'wholehearted suggestion' that he hoped Kirstein would 'take in friendly part'. The young impresario should 'charge his whole experience to date to profit and loss, congratulate himself on having helped to get better dancing into the 
opera house, shake hands cordially with Mr. Balanchine, and get to work starting an American ballet'. ${ }^{2}$

Kirstein did not welcome the suggestion and dashed off a long letter to the editor pointing out the critic's 'antipathy to the form of ballet' and attacking his 'chauvinist construction' of the word 'American'. ${ }^{13}$ However, in less than a year, Kirstein had experienced a change of heart and founded Ballet Caravan. What prompted this is unknown, although Balanchine's new Broadway career may have played a role in the decision. ${ }^{14}$ According to the official statement, duly relayed by Martin to readers of his Sunday column, 'Ballet Caravan is neither a secession from nor a part of the American Ballet, but a collective arrangement of its members, enjoying the good wishes of the directors of the American ballet itself' ${ }^{15}$ With Ballet Caravan, Kirstein set out create a ballet company with something of the physiognomy of a modern dance group. Initially the new company had only twelve dancers and was thus closer in size to a modern dance 'group' than a full-fledged ballet company. Dancers were listed alphabetically, rather than by rank, and all the choreography was by the dancers - the case of many left-wing troupes, which sought to develop their own choreographers from within the group. The emphasis, as Water Terry remarked in his review of the company's Bennington debut, was 'on dance and performance; not on elaborate lighting effects and multi-colored settings', ${ }^{16}$ a spartan approach more typical of modern dance than ballet. The thrust of the new company was American; its goal to develop 'a new repertory by native choreographers, musicians, and designers working with national themes' (as Kirstein wrote) as well as new audiences. ${ }^{17}$ 'At first our ideas were disjointed and vague', recalled Caravan member Ruthanna Boris,

but gradually they connected themselves and emerged as a beautiful, possible dream - a dream of American ballet dancers dancing America! ... When Bennington applauded us we felt more than ever that we were headed in the right direction, for there our audience was composed of young dancers who, though their technique was different, had been doing for a long time what we were beginning to do. ${ }^{18}$

The company played in movie houses as well as civic auditoriums, reconverted barns, and assembly halls. Frances Hawkins, who bookcd the company's cross-country tours, made a point of tapping college audiences - the same audiences that Martha Graham and other moderns were courting at the same time. In fact, from the start, Ballet Caravan targeted the influential audience that had crystallised for modern dance since the early 1930s. The company performed not once but twice (in 1936 and 1937) at the Bennington College Summer School of the Dance, that 'fortress of modern dance', as Kirstein called it, and gave its first New York performances at the 92nd Street Y, another venue closely identified with modern dance. When Kirstein remarked in Thirty Years that 'in an important sense, Modern Dance may be said to have launched Ballet Caravan', he was hardly exaggerating. ${ }^{19}$ This new audience had little in common with High Bohemia, where talent and intellect seemed to go hand-in-hand with money and breeding, which Kirstein had assiduously 
cultivated for the American Ballet. Although individual collaborators, including Virgil Thomson, may have frequented the Askew salon and dined with the Stettheimers, epicentres of New York's cosmopolitan-minded High Bohemia, ${ }^{20}$ the Caravan largely bypassed this audience, even in New York. Instead, the company aligned itself with a the city's new, home-grown intelligensia - children of the great turn-of-the-century migration from the shtetls of Eastern Europe, educated in the city's free colleges, and assimilated through the Left and organisations of the New Deal.

A key figure in navigating this modern dance world was Martha Graham. Just when she and Kirstein met is unclear, although a likely guess is 1935, when he began to exempt her from his blanket condemnation of modern dance, expressing admiration for 'her personal integrity, her persistence, her success, and her talent for composition'. ${ }^{21}$ When they did finally meet, 'he became addicted'. ${ }^{22}$ He took to hanging out at her studio; they wrote to one another, exchanging ideas as well as letters, although only Graham's seem to have survived. According to her biographer Agnes de Mille, he never gave her a penny. But he was around, 'counseling and criticizing, writing, praising, and courting'. ${ }^{23}$ His influence on Graham was palpable in the theatricality of her productions in the late $1930 \mathrm{~s}$, in the new emphasis on subject matter and a powerful sense of the contemporary, as exemplified by works such as Immediate Tragedy, inspired by the terrifying events in Spain. ${ }^{24}$ "What is known as "modern" dance, or contemporary dance,' she wrote to him around 1937,

can be the means of cleansing the eye and of freeing the body. It fails when it becomes only 'modern', when it makes a fetish of the colloquial, the immediate, and seeks to exist without structure, without the anatomy that is timeless. If it is pure it must dramatise its purity to be seen. That is to me what being theatrical means. ${ }^{25}$

In 1938 or 1939 she confided:

Just seeing your outlines ... for 'Memorial Day' [an unrealized ballet about the Givil War] ha[s] taught me the value of orderly and consummated thought. ... There is so much I cannot do - or have not been able to do.

Sometimes she gave him advice:

I ... feel that at times you need a more lateral sweep to your choreography. You need to use the extended stage - an expansion, spread, in gesture, in leap. I feel ballet must adjust itself to the American scale, that is lateral in concept and expansive in quality.

Always she gave him courage:

I hope nothing will interfere with 'Memorial Day'. At this time it is terribly important that we sing our own songs here. I do not feel '[American] Document' to be right, or perhaps even good - but it is important that people hear what it says again even more important than when I did it. And it is terribly important that 'Memorial Day' be done with its final accent or courage - and banners in the sky. Do you remember the Whitman poem - with the Child and the Father and the Pennant against the sky?

The two shared not only a love of Walt Whitman but also Hart Crane. The inspiration for Pocahontas, a 1936 Caravan ballet, was Crane's epigraph for Part II of The Bridge - 'The Dance-Powhatan's Daughter', while a line from the 


\section{DANCE OBSERVER

\begin{tabular}{|c|c|c|}
\hline Yad $\psi ;, \operatorname{Sn} 8$ & OSTTOEDR, 1389 & Fiferes Cabs per Orp \\
\hline
\end{tabular}

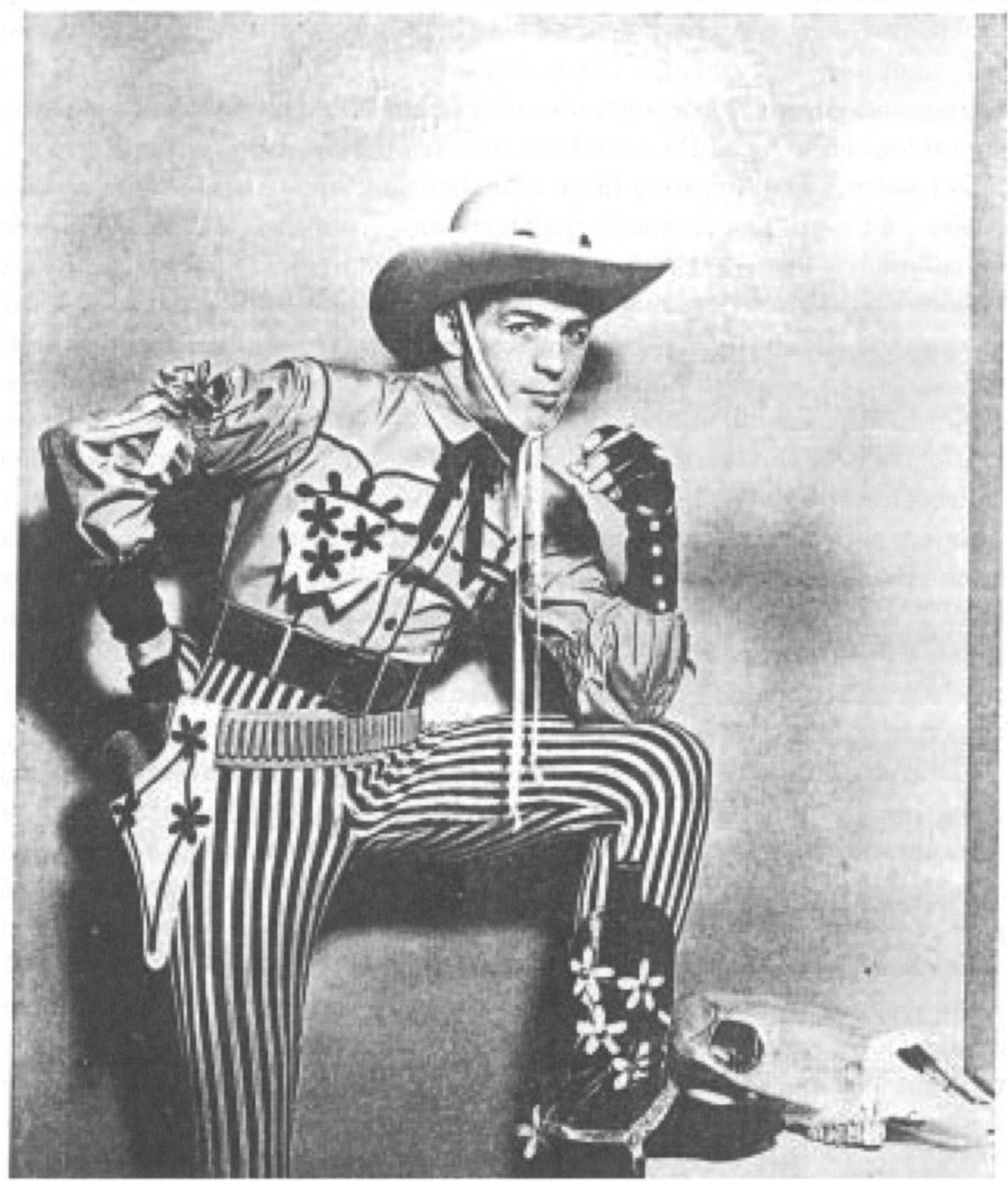

Fig. 2. Dance Observer cover from October 1938 showing Eugene Loring of Ballet Caravan in the title role of Billy the Kid.

same poem inspired the title of Graham's Appalachian Spring eight years later. ${ }^{26}$ With a magnificent score by Aaron Copland, who had earlier composed Billy the Kid, Appalachian Spring revealed to what extent she had taken Kirstein's criticism of her 'unmelodic and trivial' music to heart. ${ }^{27}$ And he called American Document, in a review of the 1938 Bennington premiere, 'the most important extended dance creation by a living American'. ${ }^{28}$ How it must have thrilled him the following year to present Billy the Kid with American Document during a Christmas 
Holiday Festival that also featured Carmelita Maracci and the Korean soloist Sai Shoki. The season, which overlapped with Ballet Theatre's final weeks of rehearsal before its debut, suggests to what extent Kirstein had aligned Ballet Caravan with modern dance. ${ }^{29}$

He also aligned it with the broad left-wing movement that grew up around the Communist Party in the 1930s. Kirstein conceived Ballet Caravan as a progressive experiment, a 'cooperative unit ' ${ }^{30}$ that would be run 'democratically' rather than hierarchically. 'I would not treat my dancers as serfs but as friends,' he later wrote. ${ }^{31}$ Dancers were listed alphabetically, and choreographers, ballet masters, and even the company's manager came from the dancers' own ranks. The company's first New York appearance accompanied by live orchestra was sponsored by the WPA Composers'-Forum Laboratory at the Federal Music Theatre. $^{32}$ In 1938 it took part in a 'huge joint performance' at the New York Hippodrome sponsored by the American Dance Association for the benefit of the North American Committee to Aid Spanish Democracy; among the other participants were the Martha Graham, Hanya Holm, Anna Sokolow, and Helen Tamiris groups. ${ }^{33}$ Ballet Caravan was the first American ballet company to be unionised, and on more than one occasion Kirstein blasted the 'open shop' that kept the Ballet Russe de Monte Carlo and other touring companies from paying decent wages. ${ }^{34}$ Several Ballet Caravan collaborators, including Paul Cadmus and Jared French, worked on WPA arts projects, and in December 1936 Kirstein himself was appointed director of the Federal Dance Project, although he resigned in less than three weeks. ${ }^{35}$

During the 1930s Kirstein was a committed leftist. He contemplated joining the Communist Party ${ }^{36}$ attended meetings addressed by labour organisers ${ }^{37}$ hob-nobbed with radicals such as the film-maker Leo Hurwitz and the dance critic Edna Ocko, ${ }^{38}$ and wrote extensively for publications such as The Nation, New Theatre, TAC Magazine, and Decision with close ties to the communistoriented left. ${ }^{39}$ (That Balanchine's earliest essay on film appeared in Dance Herald, a monthly published by the left-wing American Dance Association, can only be explained by Kirstein's political connections. $)^{40}$ Kirstein joined the League of American Writers and was active in the John Reed Club, organisations later identificd as Communist 'fronts'. In April 1935 he signed a call for a convention of American revolutionary writers; in 1939, an appeal for 'greater unity of the anti-fascist forces and stengthening of the front against aggression through closer cooperation with the Soviet Union' that was published in the September issue of Soviet Russia Today. He was later 'named' by friendly witnesses testifying in hearings before the Dies and other committees investigating 'un-American' activities. ${ }^{41}$ Well into the 1950 s his associates included party members and selfdescribed 'fellow travelers' such as John Houseman, who produced the Playhouse 90 version of the New York City Ballet's Nutcracker televised in $1958 .{ }^{42}$ Kirstein's FBI files, released under the Freedom of Information Act, indicate that his passport applications were routinely scrutinised and that the same left-wing associations appeared on FBI name checks as late as 1985, when he was invited to the White House to receive an award. 
Although Kirstein apparently found it easy to compartmentalise his life, his 'communist friends' and 'activities' - as he referred to them in the mid-1930s ${ }^{43}-$ left a discernible mark on both his thinking and his creative work. A cultural elitist, he was also a populist. He criticised the 'snob Parisian chic' of the Colonel de Basil Ballet Russe (or 'Slavo-International company', as he once called it), and did all he could to divorce ballet in general from its pervasive association with social privilege or 'snobbish preference', arguing that ballet's 'grammar of gesture and movement' was 'legible' even to unschooled audiences of workers. ${ }^{44}$ In a letter to The New York Times he expressed the hope that 'ballet would be in America a popular, widely loved institution, as in Russia today, not the property of the rich, as before the revolution'. ${ }^{5}$ 'The ballet,' he asserted elsewhere, 'is not an aristocratic form because of its association with emperors, but because of its connections with the greatest poets, painters, musicians and dancers of the past and present. It is an aristocratic form in an artistic sense. ${ }^{46}$ With Ballet Caravan he sought to embody this idea, uncoupling the aspiration to creative excellence from both wealth and social snobbery. He would do this again, even more dramatically, in the early years of the New York City Ballet.

As early as the 1922 Matthew Josephson had challenged Americans to create an indigenous art by 'plung[ing] ... into that effervescent ... milieu ... where ... the Cinemas transport us, the newspapers intone their gaudy jargon ... and skyscrapers rise lyrically to the exotic rhythm of jazz bands'. ${ }^{47}$ Like many American artists, Kirstein discovered America through European eyes. 'I wanted an everyday, ordinary setting rendered magical,' he wrote in Thirty Years. 'I made Cocteau's philosophy' - his " "rehabilitation of the commonplace"' - 'mine'. ${ }^{48}$ But Kirstein gave this philosophy a contemporary, leftist twist. Mac, the gas pump protagonist of Filling Station, was a proletarian hero, as was the cowboyturned-outlaw Billy the Kid. As characters, they belonged not only to the American imaginary but also to the new breed of American working-class heroes popularised in proletarian dramas like Stevedore and epitomised by the actor James Cagney, the subject of a long, adulatory article by Kirstein published in New Theatre. ${ }^{49}$

The Communist Party stood in the forefront of the struggle for black civil rights. This was one aspect of its ideology that Kirstein never abandoned. From the first he spoke of Balanchine's interest in having an integrated company. 'He would take 4 white girls and 4 white boys, about sixteen yrs. old and 8 of the same, negros,' he explained to A. Everett ('Chick') Austin in $1933 .{ }^{50}$ The following year, in the New Theatre essay 'Revolutionary Ballet Forms', he listed among the various points of 'Balanchine's articulate program' the 'use of negroes in conjunction with white dancers'. ${ }^{51}$ Was this Balanchine's goal or Kirstein's? In a eulogy for Carl Van Vechten in 1964, Kirstein spoke of his debt to the writer who introduced him 'to the first Negro [he] had ever met'.

I was unable, raised in Boston, insulated by Harvard to imagine that there existed in the world, not to say New York City, a marvelous jungle called Harlem, where dancers of the grace, gift and intensity of a Nijinsky existed, even though they lacked the opportunity of imperial patronage and academic training. 
When we have the terrific burden of racism on our hands, it is decent to remember those white pioneers who sparked the present overwhelming crusade. Carl was perhaps the most important figure in this movement during my youth. ${ }^{52}$

Kirstein marched in Selma in the 1960s. He generously supported AfricanAmerican artists like Janet Collins (who received studio space at the School of American Ballet during her early days in New York) and organisations such as the Dance Theatre of Harlem; in 1950 no fewer than ten African-American students were enrolled in the SAB summer course. ${ }^{53}$ Given this history, it is possible - indeed likely - that Kirstein was ascribing to Balanchine a vision of racial harmony that was really his own. In any event, nothing ever came of the mixed company.

Kirstein's ballet Tom suffered a similar fatc. Inspircd by Uncle Tom's Cabin, the ballet went through numerous transmutations, as Kirstein and his librettist, the poet e.e. cummings, sought an approach that would do justice to the theme. 'Cummings', he wrote after one of their meetings,

visualized Uncle Tom as a simple ballet, ... with many silences filled only by the natural noise of feet. It opens with Eliza cursing thrice. ... We talked abt. possible atmosphere: Parade, minstrel show or side show or realistic: not Green Pastures. ${ }^{54}$

The music, which Virgil Thomson was supposed to write but never did, proved a stumbling block. Kirstein had better luck with Ben Shahn, whose portrait of Tom served as the frontispiece of the published libretto. He visited his studio in Greenwich Village and went to Rikers Island to see the WPA-sponsored murals that Shahn was painting in the new prison. Shahn urged Kirstein to join the Communist Party. ${ }^{55}$

Others pressed him to help the movement. Someone had the idea for him to write book reviews for The New Masses (he was interested but never did). ${ }^{56}$ Someone else had the idea for him to direct a 'big pageant ballet with massed workers groups ... and flags and German workers' songs' that Kirstein called 'Red Hydra'. ${ }^{57}$ This too came to nought. He gave moncy to descrving causes (likc New Theatre and The Southern Worker), slipped the odd bill to impecunious dancers, and paid artists out of his own pocket. ${ }^{58}$ In the end, Kirstein never joined the Party. Still, he remained within the Party's vast cultural web and made Ballet Caravan at least partly a member of its intellectual and artistic polity.

Finally, Kirstein associated Ballet Caravan with the left-liberal political elite that came to power with the Roosevelt administration in the 1930s. In 1941 the company, now united with Balanchine's defunct American Ballet and rebaptised American Ballet Caravan, toured Latin America under the semi-official auspices of the U.S. Department of State. This Good Neighbor gesture, coinciding with heightened concern on the part of American policymakers about the threat of Nazi infiltration, was organised through the good offices of the new Coordinator of Inter-American Affairs, Kirstein's old friend Nelson A. Rockefeller. More than $\$ 140,000$ in government funds flowed into the company's coffers. ${ }^{59}$

The purpose of the tour, as summarised by Kirstein in one of many reports and drafts of reports sent to Rockefeller's office, was to 'further the lyric arts in 


\section{DANCE OBSERVER}

YOUWE SX, NLMEES NINE

PRice is cents

HCVIMEET. 1939

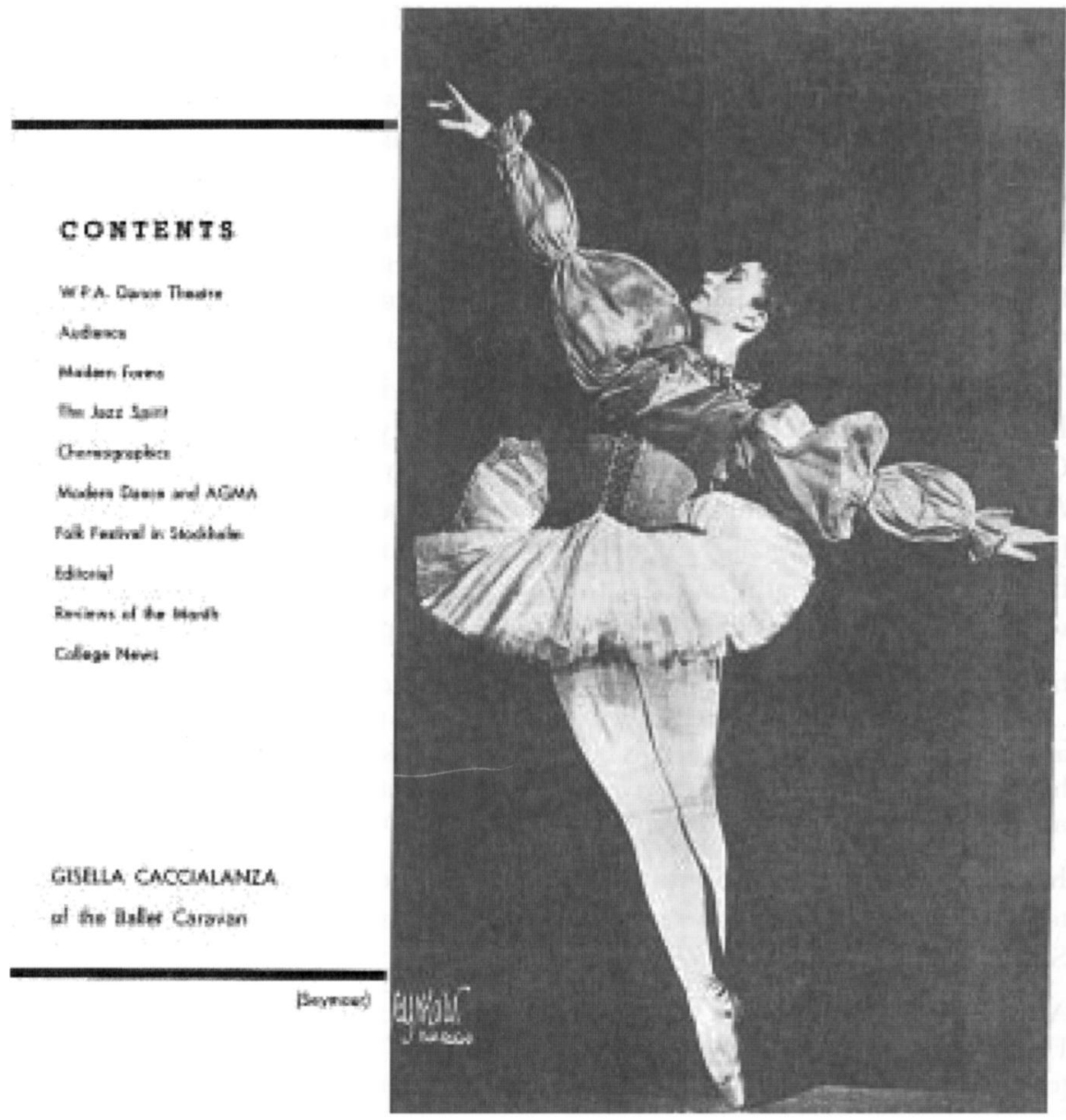

Fig. 3. Dance Observer cover from November 1939 showing Gisella Caccialanza of Ballet Caravan.

the American republics by the creation and execution of music and stage works of high quality and broad popular appeal' and to demonstrate 'in concrete form ... the interest of the United States in creative cultural movements' - this in a part of the world where few believed the United States had anything 'to contribute to the field of creative art' ${ }^{60}$ (Rockefeller's Latin American propaganda initiative also included a programme for the production and exchange of 'non-theatrical' films as well as an exhibition of contemporary American paintings and watercolours. ${ }^{61}$ The company visited every South American 
country except Bolivia and Paraguay between June and November 1941. With sixteen ballets and thirty-five dancers (plus Balanchine, the troupe's 'choreographic director', conductor Emanuel Balaban, two pianists, two singers, a wardrobe mistress, technical supervisor, and stage manager), this was Kirstein's biggest undertaking yet - a logistical nightmare that challenged its director general to invent solutions to problems he couldn't have imagined.

Kirstcin had conccived the tour on a grand scale. In addition to regular performances of the ballet, it included a number of secondary activities. One was the special folk music project, which 'undertook', as Kirstein wrote,

with the cooperation of the librarian of Congress and with the collaboration of local Government agencies and musicologists, to collect original folk songs. Over 250 original songs, engraved on permanent acetate and aluminum discs, were deposited in the Library of American Folk Song of the Music Division of the Library of Congress as a result of this project. ${ }^{62}$

The project was carried out by two folklore specialists, Seamus Doyle of the Department of Phonetics of New York University, and his assistant, Preston Corsa, who also doubled as singers in Lew Christensen's Mexican-Indian ballet Pastorela. The two met 'innumerable native singers and dancers and nearly every folk-lore expert in Brazil, Uruguay, Argentina, Chile and Peru'. ${ }^{63}$ The project fired Kirstein with enthusiasm. 'I thought Brazil was going to be a descrt,' he wrote to the Music Division director, Dr. Harold Spivacke,

but they got about 200 songs and made a very careful study of the discoteca in Sao Paulo. ... [Alan] Lomax could work in Brazil for 2 yrs. easily; in the north, state of Alagoas, then along the coast from Pernambuco to Bahia, then in the state of Sao Paolo. But we got a hors d'oeuvre cross-section of all types. We heard, but could not get, a hair raising macumba recording from Bahia. ${ }^{64}$

Kirstein's enthusiasm for South America soon found a creative outlet. He itched to commission. 'Nelson promises me money for commissions, "soon", he told Spivacke.

Anyway I have myself paid - or in royalties will have paid $\$ 500$, out of my pocket to Francisco Mignone for his unpublished, unperformed IV Fantasia Brasiliera: wc arc trying to mount it at once. I want very much to have that come under the Library-Coolidge busincss. Is it possible? I am also, if I make expenses here, going to commission Camargo Guarnieri of Sao Paolo to do a ballet with Mario d'Andrade. ${ }^{65}$

Nothing came of the Guarnieri project. But several other commissions did materialise, including Fantasia Brasileira. 'I wished to bring back South American works with me,' Kirstein explained in a detailed report on Sao Paolo. 'Hence I commissioned various painters and musicians to do work for us, as many as possible while we were in town, so that the full value of the collaboration could be immediately publicized. ${ }^{66}$ Among the recipients of his largesse were Cándido Portinari and Tomás Santa Rosa, who did new scenery and costumes for Serenade and Apollo, respectively, and Erico Bianco, who designed Fantasia Brasileira. Arriving in Buenos Aires, Kirstein commissioned a second South American ballet, this one on Argentine ranch life called Estancia. Although the ballet, 
inspired by the pampas epic Martín Fierro, never materialised, both Horacio Butler's designs and Alberto Ginastera's score ended up in the United States. Finally, in Santiago de Chile, Kirstein 'personally paid' Domingo de Santa Cruz for the performing rights of his Cinco Piezas Breves to be used as a ballet. ${ }^{67}$ The tour also prompted a flurry of articles by Kirstein on South American artists, composers, and literary figures, and in 1943 the publication of the novel For My Brother, based on a Mexican sojourn. ${ }^{68}$

Kirstein's reports home did not limit their comments to artistic matters. They also contained information of a political nature. Although officially neutral in the European conflict, Argentina was a haven for Nazi sympathisers, and Kirstein carefully noted the political sympathies of the social and artistic personalities he met. Thus, Alejo González Garano, president of the Society of Engravers and Water-Colorists, was 'passionately pro-U.S. and pro-Ally', while Ignacio Pirovano, the director of the 'chic interior decorating house of Comte', was 'pro-Vichy', like most of the " "smart" people here, being dominantly affected by French taste and Paris as of 1930-40'. María Rosa Oliver was a 'good writer', the translator of O'Neill, Dreiser, and Sherwood Anderson, and 'should certainly be brought to the United States'. As for Victoria Ocampo, a 'great blue-stocking' supporting the magazines Sur and Les Lettres Françaises (a new Gaullist review), 'importer of many German and Republican Spanish intellectual refugees, and the virtual arbiter of Argentine artistic and literary life', it was simply 'untrue' that she hated $\Lambda$ mericans. Her sister Angelica was 'also a good friend to the USA'. ${ }^{69}$ In Rio de Janeiro he met a woman he thought 'wd. be damn useful in Nat. Defense'. Her name was Sylvia Regis de Oliviera; she was the daughter of the former Ambassador to England, spoke English 'perfectly', and had 'worked on Latin American stuff for the BBC' ${ }^{70}$ Kirstein also reported on suspicious political and military activity.

In 1942 Kirstein returned to South America to purchase painting and sculpture for the Museum of Modern Art. (The following year he wrote the catalogue for the exhibition The Latin American Collection of the Museum of Modern Art.) But he may well have been up to something more. According to a War Department memo, he was in Brazil in June 1942

purportedly on a mission connected with the War Department to purchase German military books which could not be obtained in the United States. Subject made no secret of his presence and purpose in Brazil but ncver made any attempt to contact the Acting Military Attache. This action on his part is considered suspicious inasmuch as he appeared to have no particular qualifications for a special mission of this kind....

On September 9, 1942, subject was interviewed in the lobby of the Pan American Airways in Panama at which time he was with the Office of the Coordinator of the Rockefeller Institute and trying to get transportation to Mexico City. The interview was concerned mainly with the pro-Nazi sentiments of [NAME BLACKED OUT], then serving with the Brazilian Army.

The War Department continued to monitor Kirstein's activities. His mail was opened, including an intercepted letter from a Buenos Aires correspondent having to do with Gaullist activities in the Argentine capital. ${ }^{71}$ Like numerous 
cultural mandarins during the Second World War, Kirstein appears to have been indulging in a gentleman's game of occasional espionage. ${ }^{72}$

Both the American Ballet and Ballet Caravan collapsed following the 1941 South American tour. Nevertheless, they had succeeded in forging ties with the larger cultural polity that would enable first Ballet Society, then the New York City Ballet to flourish in the postwar world. The Balanchine-Kirstein enterprise embodicd an idea of the 'modern' that offered many parallels with modern dance; it depended upon networks shaped by the cultural left of 1930s and survived in part because of the philanthropy of the mandarin elite. ${ }^{73}$ Institutions do not spring fully formed into the world. Their identity coalesces gradually, through a process of mediation and contextualisation, by tapping into existing social, cultural, and ideological frameworks and then changing them. The conjoining of experimentalism, populism, and elitism in the New York City Ballet of the late 1940s and 1950s, the irony of producing 'advanced' ballets like Agon at a popular-priced house like City Center for a sophisticated, 'intellectual' audience, had its origin in what historian Michael Denning has called the 'cultural front' of the 1930s - the 'encounter between a powerful democratic movement and the modern cultural apparatuses of mass entertainment and education'. ${ }^{74}$ This alignment of social and cultural forces collapsed in the 1960s. But in the intervening decades its belief in the redeeming power of art, modern forms of expression, and the uncoupling of elitism from social and economic privilege helped transform New York from a cultural backwater into a major international capital of the arts, including dance.

\section{NOTES}

1. Lincoln Kirstein (1907-1996) was the Harvard-educated arts patron and influential dance writer who brought George Balanchine to the United States in 1933 and, with Balanchine, cofounded both the New York City Ballet and its affiliated School of American Ballet. He was the author of numerous books, including Dance: A Short History of Classic Theatrical Dancing (New York: Putnam, 1935), Movement and Metaphor: Four Centuries of Ballet (New York: Praeger, 1970), and Thirty Years: The New York City Ballet (New York: Knopf, 1978). For an overview of Kirstein's contributions to American ballet, see Nancy Reynolds, 'In His Image: Diaghilev and Lincoln Kirstein', in The Ballets Russes and Its World, ed. Lynn Garafola and Nancy Van Norman Baer (New Haven: Yale University Press, 1999), pp. 291-311.

2. Ballet Caravan made its debut at Bennington on 17-18 July 1936 and returned in 1937 for a performance on 24 July. Kirstein, assisted by members of Ballet Caravan, gave a lecture-demonstration during each visit. See Sali Ann Kriegsman, Modern Dance in America: The Bennington Years (Boston: G. K. Hall, 1981), pp. 57, 69.

3. Ballet Caravan performed at the 92nd Street $Y$ on 31 October and 1 November 1936 and on 2 January 1938. The company was the opening attraction of the 1936-1937 season. See Naomi M. Jackson, Modern Dance and Fewish Culture at the 92nd Street $Y$ (Hanover, N.H.: UPNE/Wesleyan University Press, 2000), p. 232. In fact, the company made its New York debut at the 'Y's' Theresa Kaufman Auditorium, as John Martin alerted readers of The Nere York Times. See John Martin, 'The Dance: Events Ahead', The New York Times [hereafter $\mathcal{N} Y T$ ] 18 Oct. 1936, X8, and 'The Dance: Jooss Ballet', NYT, 25 Oct. 1936, $\mathrm{X} 8$.

4. The company performed in the popular Student Dance Recitals at Washington Irving 
High School on 28 January 1939. See John Martin, 'The Dance: Felicia Sorel, Composer', NYT, 22 Jan. 1939, p. 122. The artists appearing in the 1938-1939 series included Carola Goya, Ted Shawn and His Men Dancers, Martha Graham and group, Doris Humphrey, Charles Weidman, and group, Tamiris and group, Harald Kreutzberg, and Hanya Holm and group. See John Martin, 'The Dance: More Plans', NTT, 25 Sept. 1938, p. 162.

5. Four ballet companies 'which make their permanent headquarters in America' were invited to take part in Dance International's ballet evening - the American Ballet, Ballet Caravan, Mordkin Ballet, and Catherine Littlefield's Philadelphia Ballet, and the Chicago Opera Ballet, directed by Ruth Page (John Martin, 'The Dance: Week's Plans', NYT, 24 Oct. 1937, p. 173).

6. "The third session in the New School's series on "The Dance in the Social Scene" on Tuesday evening will have Lincoln Kirstein as speaker. His subject will be the development of the ballet. Members of the Ballet Caravan will demonstrate the various points of the lecture' (Martin, 'The Dance: Jooss Ballet Appearance', NYT, 11 Oct. 1936, X8). The programme took place on 13 October 1936, that is, shortly before Ballet Caravan's New York debut at the 92nd Street Y.

7. For this season, see the following articles by John Martin: 'The Dance: Holiday Festival Season', NYT, 17 Dec. 1939, p. 130; 'The Dance: Holiday Schedule', NTT, 24 Dec. 1939, p. 88; 'Festival of Dance Has Its Opening', NYT, 27 Dec. 1939, p. 17; 'Martha Graham in Dance Festival', NYT, 28 Dec. 1939, p. 10; 'The Dance: The Holiday Festival', NYT, 29 Dec. 1939, p. 10; 'Miss Maracci Bows at Dance Festival', NKT, 1 Jan. 1940, p. 25. The Korean dance recitalist Sai Shoki and the West Coast dancer Carmelita Maracci rounded out the programming. Maracci was a last-minutc replaccment for Harald Krcutzberg, who had been 'refused permission to travel by the German government' ('Holiday Dance Festival', NYT, 10 Dec. 1939, p. 65).

8. The Ballet Caravan dancers featured on the cover of Dance Observer were Lew Christensen in Filling Station (May 1938), Eugene Loring in Billy the Kid (Oct. 1938), Erick Hawkins (June-July 1939), and Giselle Caccialanza (Nov. 1939). Kirstein contributed several articles to Dance Observer, including 'Ballet: Introduction and Credo' (Oct. 1937, p. 94); 'The Ballet: Sad but Hopeful' (Nov. 1938, p. 113); 'The Ballet: Tyranny and Blackmail' (Dec. 1937, p. 129); 'Dance International 1900-1937' (Jan. 1938, pp. 6-7); 'About "Billy the Kid"' (Oct. 1938, p. 116); and 'Audience' (Nov. 1939, pp. 282-3).

9. Lincoln Kirstein, 'Ballet: Record and Augury', Theatre Arts, 24, no. 9 (Sept. 1940), p. 657.

10. Quoted in John Martin, 'The Dance: Ballet Debut', NTT, 24 Feb. 1935, p. 19.

11. John Martin, 'The Dance: The Ballet', .NYT, 10 Mar. 1935, p. 23.

12. John Martin, 'The Dancc: At thc Opcra', NYT, 18 Aug. 1935, X5.

13. Lincoln Kirstein, 'The Dance: A Letter', NTT, 25 Aug. 1935, X5. In Blast at Ballet, which was published in 1937, Kirstein partly changed his position. 'The first performances of the American Ballet Company in New York City and on tour in 1935, pleased many people and disappointed others', he wrote. 'I think it was John Martin who called it Les Ballets 1935, and with some reason' (Ballet: Bias and Belief: 'Three Pamphlets Collected' and Other Dance Writings of Lincoln Kirstein, ed. and introd. by Nancy Reynolds [New York: Dance Horizons, 1933], p. 184).

14. Kirstein later claimed that with the management of the school increasingly turned over to Eugenie Ouroussow, he 'lacked a vocation' (Lincoln Kirstein, Thirty Years: New York City Ballet, rev. ed. [New York: Knopf, 1978], p. 68). However, Kirstein is not the most reliable guide to his own life, and in his autobiographical writings, what is left unsaid is sometimes more important than what he chooses to include. In Thirty Years Kirstein says that he dccidcd to form Ballct Caravan 'carly in 1936', a datc that coincided with Balanchinc's first Broadway work: Ziegfeld Follies opened in.January 1936 and On Your Toes the following April.

15. John Martin, 'The Dance: A New Troupe', NMT, 28 June 1936, X6.

16. Quoted in Kriegsman, Modern Dance in America, p. 58.

17. Kirstein, Thirty Years, p. 69.

18. Quoted in Kriegsman, Modern Dance in America, p. 58.

19. Kirstein, Thirty Years, p. 69. 
20. For High Bohemia, although this is not a term the authors use, see Nicholas Fox Weber, Patron Saints: Five Rebels Who Opened America to a New Art, 1928-1943 (New York: Knopf, 1992), and Eugene R. Gaddis, Magician of the Modern: Chick Austin and the Transformation of the Arts in America (New York: Knopf, 2000).

21. Lincoln Kirstein, 'The Dance: Some American Dancers', The Nation, 27 Feb. 1935, p. 258.

22. Agnes de Mille, Martha: The Life and Work of Martha Graham (New York: Random House, 1992), p. 229.

23. Ibid., p. 240.

24. For Kirstein's thrilling description of Graham's solo, see his essay 'Kirstein, 1937', in Martha Graham: The Early Years (1937), cd. Merlc Armitagc (Ncw York: Da Capo, 1978), p. 33.

25. This and the excerpts that follow are from two undated letters by Graham in Box 6, Folder 102, Lincoln Kirstein Papers (hereafter 'Kirstein Papers'), Jerome Robbins Dance Division, New York Public Library for the Performing Arts. Previously unpublished writing by Lincoln Kirstein is copyright [2004] by the New York Public Library (Astor, Lenox and Tilden Foundations) and is used here with permission.

26. Kirstein, Thirty Years, p. 75; Gail Levin, 'Aaron Copland's America', in Levin and Judith Tick, Aaron Copland's America: A Cultural Perspective (New York: Watson-Guptill Publications, 2000), p. 100.

27. The phrase comes from Kirstein's article 'The Dance: Some American Dancers', The Nation, 27 Feb. 1935, p. 258.

28. Lincoln Kirstein, 'Martha Graham at Bennington', The Nation, 3 Sept. 1938, p. 230.

29. See note 6 above. This season at the St James Theatre was also a blucprint for Ballet Society, which not only produced Merce Cunningham but also presented programmes of modern and Javanese dance. In Thirty Years Kirstein mentions having 'skittish conversations about being absorbed by the Ballet Theatre, which Lucia Chase was now directing away from the original Russian orientation of Mikhail Mordkin, her teacher. Our aimless flirtation with the Ballet Theatre continued until I went into the Army' (p. 79). Several Caravan dancers, including Eugene Loring and Alicia Alonso, joined the new enterprise.

30. Joseph Arnold Kaye, 'Dance in Review', Dance, Oct. 1936, p. 30.

31. Kirstein, Thirty Years, p. 70.

32. Anatole Chujoy, 'Dance in Review', Dance, Apr. 1938, p. 30; John Martin, 'Caravan Dancers in Three Ballets', NTT, 19 Feb. 1938, p. 18. In Thirty Years Kirstein described these performances as 'put[ting] some sort of seal of approval on our repertory' (p. 73).

33. John Martin, 'The Dancc: Evcnts Ahcad', NYT, 23 Jan. 1938, X8. The programme, sponsored by the American Dance Association, took place on Friday, January 28.

34. See, for example, 'Kirstein Blasts Open Shop', Dance, Mar. 1940, pp. 8-9, and his letter to the editor, Dance Observer, May 1940, p. 74. For an overview of unionisation efforts in the dance field, see 'AGMA: Signs Ballet Russe', Dance, Apr. 1940, p. 6.

35. His plan to produce a revue with the working title, 'The History of American Dancing', in which all the project groups would collaborate, met with such stiff resistence from the choreographic staff, which accused him of anti-modern dance views, that he quickly resigned. His production manager, Steven Karnot, was not only a former director of the Federal 'T'heatre Project's Brooklyn and Queens unit but also a contributing editor of New Theatre. See 'WPA Shifts Head of Dance Project', NTT, 24 Dec. 1936, p. 22; John Martin, 'The Dance: Spring Plans', NIT, 17 Jan. 1937, p. 160. The fullest account appeared in the February 1937 issue of Dance ('New Project Head', pp. 24-25). For another perspective, see Christena L. Schlundt, 'Tamiris: A Chronicle of Her Dance Career 1927-1955', Studies in Dance History, 1, no. 1 (Fall/Winter 1989-1990), p. 98.

36. See, for instance, his diary entries for 16 Oct., 26 Oct., and 8 Nov. 1934 (Lincoln Kirstein Diaries, Jerome Robbins Dance Division, New York Public Library for the Performing Arts).

37. See, for instance, his diary entries for 15 Oct. and 26 Oct. 1934. Kirstein alludes to this in Thirty Years: 'I was also attracted to several young union organisers working in the South and found myself embroiled in polemical battles which had little to do with art but a lot with life' (p. 81). 
38. For Leo Hurwitz, who was also a member of the editorial board of New Theatre, see diary entries for 1 Aug., 12 Sept., and 16 Oct. 1934; for Edna Ocko, who edited the magazine's dance pages, 5 and 15 Nov. 1934.

39. For a list of Kirstein's published writings, see Harvey Simmonds, Louis H. Silverstein, and Nancy Lasalle, Lincoln Kirstein: The Published Writings 1922-1977: A First Bibliography (New Haven: Yale University Library, 1978).

40. Georges [sic] Balanchine, 'The Ballet and the Film: The Making of the Goldwyn Follies', Dance Herald, 1, no. 6 (Apr. 1938), pp. 1, 7-8. This was the lead article of an issue on 'Dance and the Film'.

41. This information is cullcd from Kirstein's FBI file, released under the Freedom of Information Act, as well as a response dated 23 March 1953 to a Rockefeller Foundation request for name checks on several individuals, including Kirstein, associated with City Center (RF12, 200R, City Center, Box 392, Folder 3391).

42. John Houseman, Unfinished Business: Memoirs 1902-1988 (New York: Applause Theatre Books, 1988), p. 384. According to Houseman, the funding for the American Shakespeare Festival Theatre, of which Kirstein was a founder and Houseman the artistic director, was fatally compromised in 1958 when the House Un-American Activities Committee, in yet another round of anti-Communist hearings, exposed the ASFT's production stage manager, Bernard Gesten. When the new manager "was on his way to call his master in Washington ... he ran into Lincoln Kirstein, who was in one of his dark moods. Lincoln told him not to be a horse's ass, to mind his own fucking business, and to keep his goddamned mouth shut. Didn't he know that half our company were Communists? ... Lincoln had, as usual, cxaggeratcd. But, as usual, there was truth in what he said. Wc had in the company to my personal knowledge, no fewer than five, besides Gersten, who had taken the Fifth Amendment - not to mention half a dozen 'fellow travelers', of whom I was, myself, the most notorious' (ibid., pp. 383-384).

43. For 'my Communist friends', see diary entry for 2 Aug. 1934; for 'my Communist activities', 28 Oct. 1934.

44. Lincoln Kirstein, 'Revolutionary Ballet Forms', New Theatre, Oct. 1934, p. 12; for the phrase 'snobbish preference', see Kirstein's 'The Dance as Theatre', New Theatre, May 1935, p. 20; for the term 'Slavo-International', his 'Stardom: Slav and Native', Dance, June 1938, p. 14.

45. Kirstein, 'The Dance: A Letter'.

46. Lincoln Kirstein, 'Ballet and the Modern Dance Today', Dance, Oct. 1936, p. 26.

47. Quoted in Levin, Aaron Copland's America, p. 21.

48. Kirstcin, Thirty Years, p. 72.

49. Forrest Clark (pseud. Lincoln Kirstein), 'James Cagney', New Theatre, Dec. 1935, pp. 14-15, 34. 'Cagney is not only a rough-neck from a down-town filling station, nor a worn-out racing-driver, nor a cocky truckman, nor a damn-good prize-fighter, nor a petty gangster, nor a traveling salesman, nor a picture-snatcher, but all of these varied characters, each perfectly realized in itself, with the inimitable addition of his own brand ... of recklessness, bitterness, anguished comedy and sober hysterical gaiety. Cagney is the perfect portrait of the American urban man and boy' (p. 15).

50. Lincoln Kirstein, Letter to A. Everett Austin, Jr, 16 July 1933, in I Remember Balanchine: Recollections of the Ballet Master by Those Who Knew Him (New York: Doubleday, 1991), p. 116. However, in his letters of 13 July and 18 July to Muriel Draper, Kirstein makes no reference either to African-American students or to an integrated company. See Muriel Draper Papers, Beinecke Library, YCAL MSS 49, Series I, Box 5, Folder 155.

51. Kirstein, 'Revolutionary Ballet Forms', p. 14.

52. Lincoln Kirstein, 'Memoir of Carl Van Vechten', 23 Dec. 1964, Box 257, Folder 21. Aaron Copland Collection, Library of Congress (hereafter LC).

53. For Janet Collins and the black students enrolled in the 1950 SAB summer course, see Eugenie Ouroussow, letter to Lincoln Kirstein, 8 Aug. 1950, Box 10, Folder 165, Kirstein Papers.

54. 30 Dec. 1933. It may well be that Kirstein suggested the minstrel show format to Martha Graham for American Document.

55. Diary, 2 and 8 Nov. 1934. 
56. Diary, 24 Oct. 1934.

57. Diary, 16 Oct. 1934.

58. Diary, 4 Sept., 7 Sept., 16 Oct., and 10 Nov. 1934. Among the dancers who were recipients of his largesse were Erick Hawkins, William Dollar, Charles Laskey, and Eugene Loring.

59. The American Ballet Caravan [report], Rockefeller Family Collection, R.G.4 (NAR/ Personal Projects), Series F966, Box 101, Folder (Lincoln Kirstein/Ballet Caravan). See also Lynn Garafola, 'Dollars for Dance: Lincoln Kirstein, City Center, and the Rockefeller Foundation', Dance Chronicle, 25, no. 1 (2002), p. 102. In fact, according to a report filcd by Kirstcin at the cnd of the tour, the total subsidy camc to $\$ 141,922.04$ ('The American Ballet Caravan', RFG, R.G.4, Series F966, Box 101, Folder [Lincoln Kirstein/Ballet Caravan], p. 1).

60. Ibid., pp. $1,3$.

61. For clippings of these undertakings, both of which involved Museum of Modern Art personnel, see the Museum of Modern Art scrapbooks for March through May 1941 in the Museum Archives (MF42.459).

62. Kirstein, 'The American Ballet Caravan', p. 6.

63. Lincoln Kirstein, 'Draft of a Preliminary Report Concerning the Tour of the American Ballet Caravan in South America, June-September 1941', n.p.

64. Lincoln Kirstein, letter to Dr Harold Spivacke, 15 July 1941, Music Division Old Correspondence, Library of Congress. Then at the start of his career as an ethnomusicologist, Alan Lomax is best known for his pioneering fieldwork on the blues and other forms of traditional Amcrican music. Much of his carly rescarch was sponsorcd by the Library of Congress, including his 1936-1937 Haitian field trip and his 1941-1942 comprehensive survey of African-American music in Coahoma County, Mississippi undertakings of which Kirstein was clearly aware. For an overview of Lomax's life and career, as well as a list of his books, principal field trips, and recordings, see the Alan Lomax Archive Website, http://www.alan-lomax.com (26/12/2004). Kirstein's project anticipated another Rockefeller-sponsored ethnomusicology project of the early war years, the unfinished documentary, It's All True, by Orson Welles, which began as a film about Brazilian carnival and morphed into the story of samba. See Michael Denning, The Cultural Front: The Laboring of American Culture in the Twentieth Century (London: Verso, 1997), p. 397.

65. Ibid.

66. Kirstein, 'Draft of a Preliminary Report', p. 12.

67. Both Bianco's designs for Fantasia Brasiliera and Butler's for Estancia are at the Museum of Modern Art. Ginastera's score is in the Library of Congress Music Division. For Santa Cruz, see Kirstein, 'Draft of a Preliminary Report', p. 26. According to an article published by Kirstein in Theatre Arts Monthly ('Latin American Music for Ballet', May 1942, pp. 329-335), Estancia was choreographed by Balanchine and performed in Buenos Aires during the Caravan tour. However, the ballet is not included in the very complete Choreography by George Balanchine: A Catalogue of Works.

68. See the entries in Lincoln Kirstein: A First Bibliography.

69. Kirstein, 'Draft of a Preliminary Report', pp. 17-18; letter to Arthur Jones, 27 July 1941, RFG, R.G.4, Series F966, Box 101, Folder (Lincoln Kirstein/Ballet Caravan).

70. Lincoln Kirstein, letter to Nelson A. Rockefeller, 26 June 1941, RFC, R.G.4, Series F966, Box 101, Folder (Lincoln Kirstein/Ballet Garavan).

71. Unsigned memo, War Department, 20 Oct. 1943. This document was in Kirstein's FBI dossicr.

72. Kirstein published several articles about the American Ballet Garavan tour, but needless to say they make no mention of any covert activities. See 'The American Ballet in Brazil: Part I of a Travel Diary', The American Dancer, Sept. 1941, pp. 8-9, 19, 23; 'The American Ballet in Argentina: Part II of a Travel Diary', The American Dancer, Oct. 1941, pp. 12-13, 25, 29; 'The American Ballet in Chile: Part III of a Travel Diary', The American Dancer, Nov. 1941, pp. 10-11, 31; 'The American Ballet in Venezuela: Part IV of a Travel Diary', The American Dancer, Dec. 1941, pp. 16-17, 30. Nicholas Jenkins, Kirstein's literary executor, 
gives a somewhat different account of Kirstein's political adventures: 'In addition to purchasing art and facilitating cultural interchange, Kirstein was, he told me, to report back in secret to Rockefeller on the dubious political sympathies of the American Embassies he visited. Soon, however, his letters to his powerful and rich patron in the government were intercepted by the State Department. Kirstein was in Brazil, where he was observing what he felt to be Axis-fond behavior by the American Ambassador, Jefferson Caffery. After the interception of the letters, Caffery arranged for the young aesthete to get a scare. Acting on the orders of the American vice-consul, the Brazilian police arrested Kirstein and threw him in jail in Sao Paulo, where he languished for a few days until Rockcfcller was ablc to arrange for his release' (Nicholas Jenkins, 'Reflections: The Great Impresario', The New Yorker, 13 Apr. 1998, p. 59).

73. For Rockefeller Foundation funding of the New York City Ballet in the 1950s, see Garafola, 'Dollars for Dance': Lincoln Kirstein, City Center, and the Rockefeller Foundation', Dance Chronicle, 25, no. 1 (2002), pp. 101-14; reprinted in Lynn Garafola, Legacies of Trwentieth-Century Dance (Middletown: Wesleyan University Press, 2005), pp. $305-16$.

74. Denning, The Cultural Front, p. xviii. For the New York City Ballet intellectual audience, see Thomas Bender, 'The New York City Ballet and the Worlds of New York Intellect', in Dance for a City: Fifty Years of the New York City Ballet, ed. Lynn Garafola, with Eric Foner (New York: Columbia University Press, 1999), pp. 53-72. 